\title{
PERIGLACIAL PROCESSES ON HEARD ISLAND, SOUTHERN INDIAN OCEAN
}

\author{
by Kevin Kiernan and Anne McConnell
}

(with four text-figures, ten plates and one table)

\begin{abstract}
Kiernan, K. \& McConnell, A. 2008 (28:xi): Periglacial processes on Heard Island, Southern Indian Ocean. Papers and Proceedings of the Royal Society of Tasmania 142(2): 1-12. https://doi.org/10.26749/rstpp.142.2.1 ISSN 0080-4703. Nature Conservation Research Group, School of Geography \& Environmental Studies, Private Bag 78, University of Tasmania, Hobart, Tasmania 7001, Australia (KK*, AM). * Author for correspondence. Email: Kevin.Kiernan@utas.edu.au
\end{abstract}

Periglacial activity on Heard Island is manifested by intense physical weathering of the longest-exposed surfaces, and hillslope forms produced by a variety of cold-climate mass wasting processes. Microrelief features include rudimentary sorted steps, terraces and polygons. No evidence of deep cryoturbation was obtained from excavations at 14 sites in moraines and no landforms indicative of discontinuous permafrost were identified. Periglacial landform development has been inhibited by the maritime climate and is more restricted than on other islands in the region due to the low altitude of the ice-free terrain, limited extent of glacier-free ground, and relatively recent deglaciation.

Key Words: periglacial processes, cryoturbation, frost action, sorted polygons, sorted terraces, climatic warming.

\section{INTRODUCTION}

Improved understanding of periglacial processes in the southern Indian Ocean is important because the maritime sub-Antarctic environment is very different from northern hemisphere periglacial environments from which most concepts in periglacial geomorphology have been developed. In contrast to the continental interiors of the northern hemisphere, the periglacial climate on sub-Antarctic islands is characterised by a low annual temperature range, cloudy skies, high precipitation totals and freeze-thaw events that are of high frequency but penetrate to only shallow depth. Thus, this environment has more in common with high tropical mountain summits than with the classical periglacial environments of northern hemisphere continental interiors (French 2007, Boelhouwers et al. 2003).

An extensive assemblage of periglacial landforms produced by frost action and other cold-climate processes has been recorded from the southern Indian Ocean islands of Marion (Hall 1979a, b, 1981, 1983b, Boelhouwers et al. 2003), Crozet (Bellair 1969a, b) and Kerguelen (Aubert de la Rue 1959, Nougier 1964, 1972, Bellair 1969a, b, Markov 1971, Hall 1983a, b). However, a recent review by Hall (2002) was limited to a single paragraph on the likely extent of periglacial landform development and periglacial processes on Heard Island, because while the existence of some periglacial landforms has previously been recorded (Colhoun \& Peterson 1986, Kiernan \& McConnell 1999, Bergstrom \& Selkirk 2000), no detailed descriptions or overview of the range of periglacial phenomena present has hitherto been available. This is a serious deficiency because Heard Island is distinctive for being the only large island in the region that lies south of the Antarctic Convergence. The purpose of the present paper is to provide the first systematic reconnaissance and interpretation of periglacial phenomena from this important site.

Heard Island (area $368 \mathrm{~km}^{2}, 73^{\circ} 32^{\prime} \mathrm{E}, 53^{\circ} 06^{\prime} \mathrm{S}$ ) is dominated by the $20-\mathrm{km}$-wide active Big Ben volcano $(2745 \mathrm{~m})$. Around the lower flanks of Big Ben are smaller subsidiary cones (Stephenson et al. 2006), and another volcanic complex, on Laurens Peninsula $(715 \mathrm{~m})$, projects $-10 \mathrm{~km}$ northwestwards (fig. 1). Most of the island is glaciercovered (Ruddell 2006) and apart from isolated rocks and buttresses on some upper slopes and Laurens Peninsula, glacier-free terrain is largely confined to below $250 \mathrm{~m}$. It consists primarily of moraines and glaciofluvial aprons, coastal deposits of sand to boulder size, aeolian sediments, and ice-abraded basalt bedrock and diamictites within the Late Miocene-Early Pliocene Drygalski Formation (Truswell et al. 2005). Vegetation cover, mostly cushion carpet and tussock grassland, is generally confined below $100 \mathrm{~m}$. The largest area of relatively gently-sloping land above this altitude is South Plateau, which is thus of particular interest for potential periglacial phenomena. However, significant glacier recession over recent decades is exposing additional areas of new bare ground (Ruddell 2006).

\section{Periglacial Climate}

Projecting high into the westerly airstream of the "Furious Fifties", Big Ben exerts a major influence on local weather. Climatic data obtained from Atlas Cove from December 1947 until March 1955 revealed a mean annual air temperature of $-1.2^{\circ} \mathrm{C}$ (seasonal variation $-4.5^{\circ} \mathrm{C}$, maximum $14^{\circ} \mathrm{C}$, minimum $\left.-9^{\circ} \mathrm{C}\right)$. Average annual precipitation was 1350 $\mathrm{mm}$, with precipitation occurring on 300 days per year and totals greatest in late summer and early autumn, when rain dominated over snow at low altitudes. Mean sea-level wind speed was $26 \mathrm{~km} / \mathrm{hr}$ (maximum $209 \mathrm{~km} / \mathrm{hr}$ ) (Allison \& Keage 1986). More recent temperature data from automatic weather stations (AWS) indicate the coldest and warmest temperatures occurred at Spit Bay $\left(-8.4^{\circ} \mathrm{C}, 20\right.$ September $1997 ; 25.3^{\circ} \mathrm{C}, 23$ June 1998) (D. Thostpers. comm.). The highest temperatures were of short duration and were associated with foehn winds (Ruddell 2001). A total of 60-80 atmospheric freeze-thaw cycles annually is evident from the AWS data (table 1). They were caused more by cyclonic disturbances than diurnal influences, and temperatures below $0^{\circ} \mathrm{C}$ rarely lasted more than a few hours at sea level (Thost \& Allison 2006). Significant climatic warming over recent decades has been manifested 


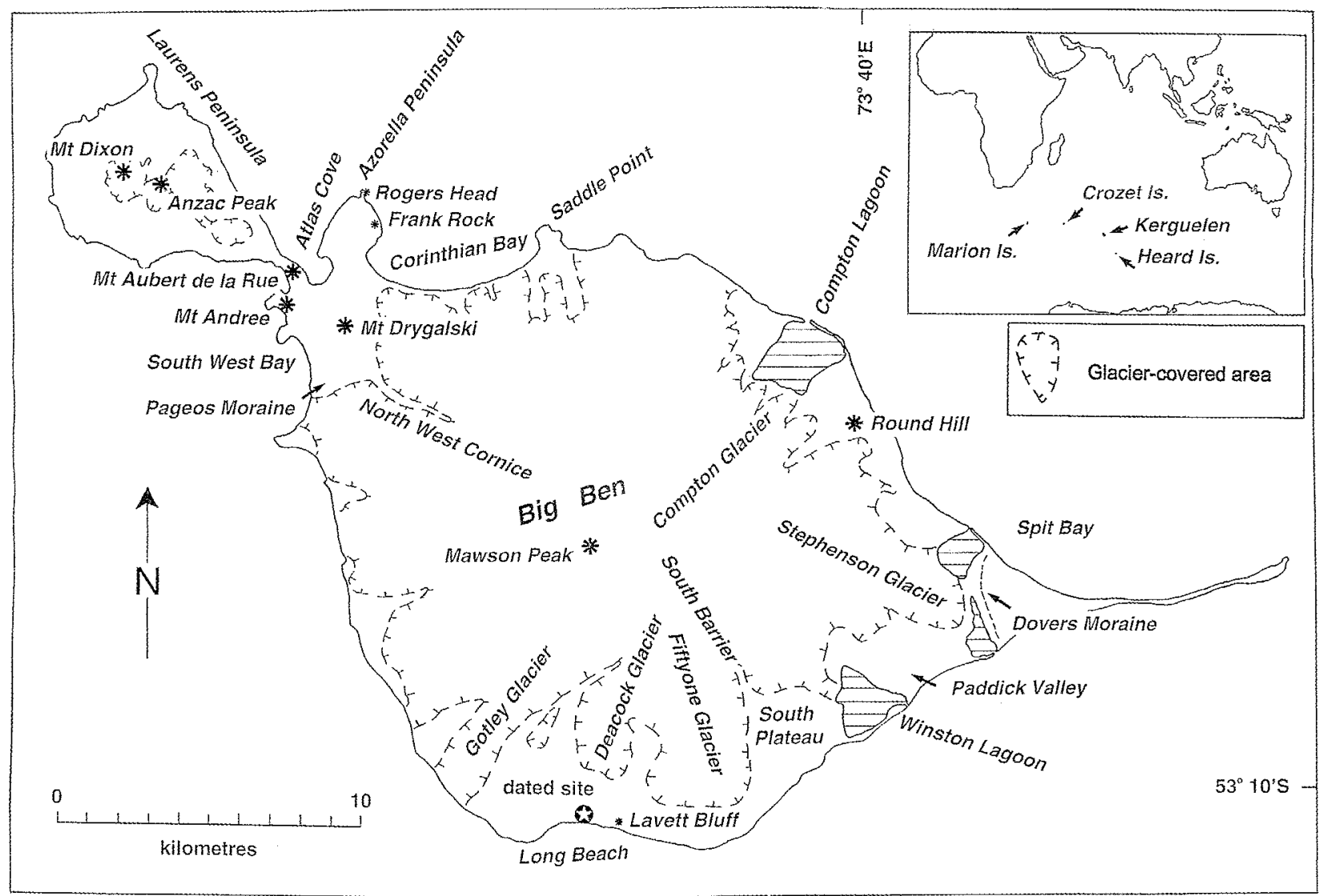

FIG. 1 - Location of Heard Island and sites referred to in the text.

TABLE 1

Atmospheric freeze-thaw cycles, 1997-2000*

\begin{tabular}{lcccccccccccc}
\hline & \multicolumn{9}{c}{ ATLAS COVE } & & & \multicolumn{5}{c}{ SPIT BAY } \\
& 1997 & 1998 & 1999 & 2000 & & 2001 & 1997 & 1998 & 1999 & 2000 & 2001 \\
\hline Jan & nd & 0 & 0 & 0 & & 0 & nd & 0 & 0 & 0 & 0 \\
Feb & nd & 0 & 0 & 0 & & 0 & nd & 0 & 0 & 0 & 0 \\
Mar & nd & 0 & 0 & 0 & & 0 & nd & 1 & 0 & 0 & 0 \\
Apr & 1 & 0 & 0 & 5 & & 0 & 0 & 2 & 2 & 3 & 1 \\
May & 1 & 5 & 4 & 2 & & 8 & 3 & 7 & 3 & 4 & 11 \\
Jun & 6 & 11 & 9 & 12 & 10 & 11 & 9 & 12 & 10 & 15 \\
Jul & 5 & 5 & 12 & 12 & & nd & 8 & 11 & 16 & 10 & nd \\
Aug & 8 & 9 & 11 & 10 & & nd & 11 & 12 & 11 & 9 & nd \\
Sep & 12 & 16 & 6 & 11 & & nd & 12 & 11 & 9 & 10 & nd \\
Oct & 7 & 10 & 11 & 12 & & nd & 10 & 9 & 14 & 10 & nd \\
Nov & 5 & 5 & 5 & 9 & nd & 7 & 4 & 10 & 12 & nd \\
Dec & 0 & 0 & 1 & 2 & nd & 0 & 0 & 2 & 1 & nd \\
Total & $(>? 45)$ & 61 & 59 & 75 & $(>18)$ & $(>? 62)$ & 66 & 79 & 69 & $(>27)$ \\
\hline
\end{tabular}

* Based on climatic data supplied by D. Thost, Antarctic CRC, Hobart.

Record for Atlas Cove commences 18 April 1997, record for Spit Bay commences 1 April 1997. nd $=$ no data. 
by a rise in the snow-line, longer melt season, rapid retreat of many glaciers, and major expansion of melt-lakes amid ice-cored moraines (Budd 2000, Kiernan \& McConnell 2002). Using glacier-climate modelling Ruddell (2006) inferred warming by $0.8^{\circ} \mathrm{C}$ since the $1940 \mathrm{~s}$.

\section{METHODS}

This paper records reconnaissance surveys of periglacial landforms undertaken incidental to other fieldwork in March 1997 and November-December 2000. The relative ages of surfaces and sediments were interpreted from morphostratigraphic relationships between landforms and deposits, radiocarbon dating of organic material contained in sediments, and historical photographs and records (Kiernan $\&$ McConnell 2002). Field measurements of the dimensions and orientation of landforms, and sediment stratigraphy, were obtained using a hand-held clinometer, compass, tape and staff, and locations were recorded by GPS. Small pits of maximum $60 \mathrm{~cm}$ depth were excavated at 14 sites on moraines to enable inspection of cryogenic disturbance and the degree of clast weathering and pedogenic alteration of the sediments. To explore surface weathering rates, the morphometry of surface clasts of $4-10 \mathrm{~cm}$ diameter from sites on Dovers Moraine (fig. 1) was determined by the methods of Kuenen (1956) and Sneed \& Folk (1958) and compared to that of shallow subsurface samples from the same sites. Ground ice classification follows Pihlainen \& Johnston (1963). Approximations of excess ice content in sediments are based on estimated volume of supernatant water in sample bags that were thawed in the laboratory. Interpretations of the periglacial environment responsible for formation of the observed landforms are based on climate data obtained up to the time the fieldwork was conducted, so as to minimise any potential distortions resulting from the most recent climate warming.

\section{RESULTS AND DISCUSSION}

\section{Physical weathering features}

Scree along the northern slopes of Laurens Peninsula, below South Barrier, and elsewhere, attests to effective physical weathering. Trachyte on $\mathrm{Mt}$ Andree has been shattered into plates generally $<40 \mathrm{~cm}$ long (maximum $>1 \mathrm{~m}$ ) and up to $20 \mathrm{~cm}$ thick (pl. 1). The lavas of Azorella Peninsula and $\mathrm{Mt}$ Dixon are less heavily shattered than adjacent pyroclastic residuals such as Rogers Head and Frank Rock. Evidence of physical weathering appears to be confined to shattering, and no granular disintegration suggestive of salt weathering was observed despite the highly maritime setting, nor were significant discolourations or salt efflorescence observed.

The significance of frost action to overall physical weathering is not always clear because some rock types appear particularly susceptible to other processes that cause disintegration (Whalley et al. 1982). For example, rare clasts of felsic basalt on Dovers Moraine are heavily shattered although more mafic basalt clasts in close proximity remain intact (pl. 2). The shattered clasts occur in areas deglaciated only during recent decades and they could not have rolled downslope from older moraines. One clast had broken down into flat, straight-edged flakes $1-4 \mathrm{~cm}$ thick, $<10 \mathrm{~cm}$ long and $-6 \mathrm{~cm}$ wide with another fragmented into blocks and shells rather than tabular flakes, the debris strewn $20-30 \mathrm{~cm}$ outside the shadow of the original -50 $\mathrm{cm}$ clast. Crack propagation does not appear due solely to freeze-thaw so much as to a predisposition to weathering imparted by mineralogy and fabric and probably involving breakdown of feldspars.

Freeze-thaw cycles at ground level are likely to be nearly twice as numerous as atmospheric cycles, hence, $>100$ cycles at ground level are likely on Heard Island (French 2007). Nevertheless, relatively limited frost shattering of recent glacial boulders is to be anticipated. A freeze amplitude of $-3^{\circ} \mathrm{C}$ is regarded by McGreevy \& Whalley (1982) as a threshold for effective mechanical weathering. Shortduration atmospheric freeze-thaw cycles of this amplitude were experienced at Atlas Cove only 11 times and at Spit Bay only 24 times between 1997 and 2000 (table 1).

To explore the possibility of more subtle physical weathering effects, morphometry of surface clasts was examined along a transect across the Dovers Moraine complex. To reduce the risk that apparent differences between sites might simply be the product of differences in original clast shapes, morphometry of shallow subsurface clasts was compared to that of the surface clasts from the same locations. Three moraines were compared: (1) immediately adjacent to the 1997 edge of the Stephenson Glacier; (2) midway across the complex, believed to have been deposited within the past 50 years; and (3) a small push moraine on

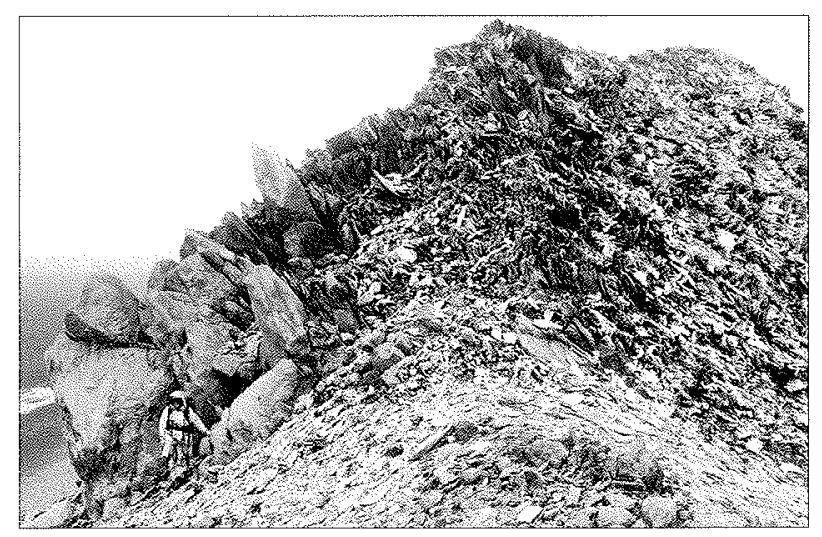

PLATE 1

Shattered trachyte at $-50 \mathrm{~m}$ altitude on southeastern slopes of $M t$ Andree.

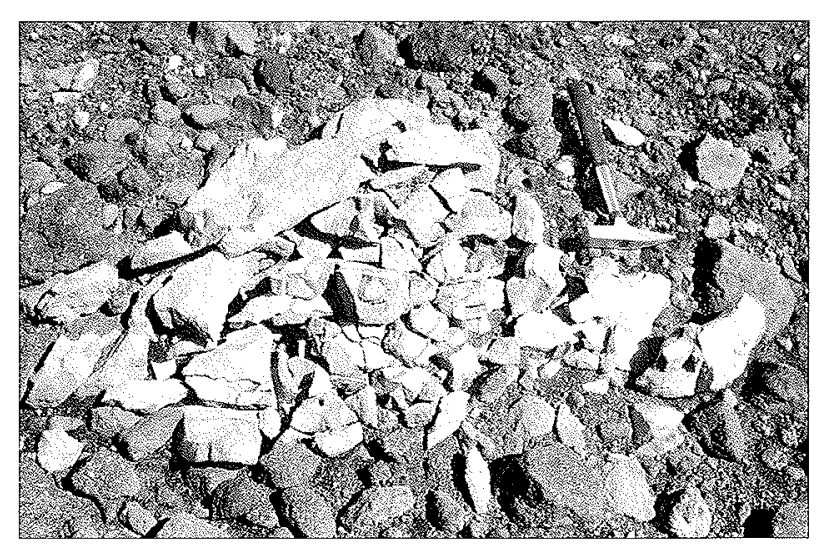

PLATE 2

Shattered clast of felsic basalt amongst unweathered, less felsic clasts at Dovers Moraine. 
the outer margin of the main complex, believed to have been deposited prior to 1850 but within the past two millenia (Kiernan \& McConnell 2002). Comparisons were restricted to mafic clasts in order to minimise the risk of differences in mineralogy causing results to depart from a time-dependent sequence.

Clasts being deposited at site 1 were assumed to be essentially unweathered given their fresh appearance and the very recent age of this moraine (Kiernan \& McConnell 2002) hence surface and subsurface samples were not differentiated. Contrasts in morphometry between surface and subsurface clasts are discernible at the other sites (fig. 2), but while mean values for rounding and sphericity of surface samples from sites 2 and 3 proved slightly lower than for the subsurface samples, they overlap at one standard deviation at each site and between sites (roundness $0.25-0.34$, sphericity $0.72-0.81$ ). Overall, the results suggest that physical weathering on the surface may have caused subtle morphometric changes to surface clasts within a few decades.

Slight rounding of subsurface clasts detected in a number of our excavated soil pits elsewhere on Heard Island, together with minor discolouration and pitting of clast surfaces, suggests subsurface chemical weathering is also occurring at some sites. Such apparent rapidity of chemical weathering was not anticipated in this environment but other evidence of relatively rapid chemical weathering was also observed, including minor karren formed on limestone southwest of Anzac Peak on Laurens Peninsula. A vegetation cover of sedge and occasional Azorella selago Orchard allows the involvement of biogenic acids on Laurens Peninsula. Small weathering pans on unvegetated basalt surfaces inland of Winston Lagoon that have been exposed for only a few decades suggest some rock dissolution by snow meltwater.

\section{Hillslope forms and processes}

Steep faces from which debris has been liberated are generally relict from glaciation, volcanism, volcanigenic debris avalanching or coastal erosion. The profile of the debris zone is often concave-upwards and incised by shallow depressions and sharper-edged channels suggestive of debris flows and fluvial incision respectively. The smoothest debris-mantled slopes typically rest at $<15^{\circ}$ but in some places up to $22^{\circ}$. Snow accumulates on them and meltwater plays an important role in causing surface wash.

Lambeth (1950) recorded a stake placed in sediments between Corinthian Bay and Mt Drygalski having moved $4.6 \mathrm{~m}$ seaward in 11 months, suggesting that solifuction was active at that time. Terraces and lobes that locally form patterned ground are described below. Effective nivation is suggested by unvegetated till at sites of persistent snow cover amid otherwise vegetated terrain east of Dovers Moraine and elsewhere.

Movement of particles by rainsplash was witnessed on slopes devegetated by penguin traffic on Mt Aubert de la Rue. Exposed regolith is susceptible to slopewash. Broad planar slopes above small alluvial fans attest to the efficacy of sheetwash, while rills are also pronounced in some areas. Less compact material encountered in the uppermost part of some excavated inspection pits, together with silt caps on clasts in some profiles, attest to subsurface wash. In periglacial environments such silt caps are typically associated with infiltration beneath snow (Corty et al. 1989).
Rapid mass movement occurs at a number of scales, commonly at sites left unstable by glacial processes. Rubble below large bedrock slabs delineated by major fractures that extend over $100 \mathrm{~m}$ along the valley wall east of the Compton Glacier terminus is attributable to stress release following glacier retreat (Harland 1957).

Rockfall is common but talus accumulation inland is inhibited by debris being removed by glaciers, although small talus cones occur beneath South Barrier and North West Cornice. Debris cones below cliffs at Laurens Peninsula and Round Hill slope at up to $30^{\circ}$.

Snow avalanches from Big Ben were heard and occasionally witnessed but dissipated on snow or glacier slopes and no geomorphological effects were recognised. At a much smaller scale, initial summer thawing of aeolian sediment in the lee of rock ridges at the foot of Mt Drygalski was observed to trigger downslope glissade of ice cemented slabs $-10 \mathrm{~cm}$ thick and up to $30-40 \mathrm{~cm}$ wide (pl. 3).

Large terraces with treads sloping at $5-7^{\circ}$ and mantled by small angular rock fragments occur between bedrock outcrops on South Plateau. They lack the long narrow form typical of cryoplanation terraces and like many other surfaces they appear to be formed on bedrock and to owe their form to lava flow morphology or glacial erosion.

Gulleys and alluvial fans attest to effective sediment movement during summer rainstorms and by meltwater released from ice-cored moraines or glaciers. Subfossil sedge obtained from silts beneath $2.5 \mathrm{~m}$ of vegetated glaciofluvial sediments on the ice-distal side of the westernmost moraine of Deacock Glacier at Long Beach (altitude $4.2 \mathrm{~m}$ ) have been radiocarbon dated to $220 \pm 113^{14} \mathrm{C}$ yrs BP (Wk 9485) (fig. 3). This indicates that a period of relative stability, during which sedge grew on relatively fine-grained sediments, was followed by instability and rapid sedimentation within the past two centuries prior to colonisation by the present-day plant cover. Many other presently stable extraglacial surfaces may be equally youthful.

\section{Periglacial microrelief features}

Stone polygons up to $8 \mathrm{~m}$ diameter occur at the southern base of Anzac Peak (Bergstrom \& Selkirk 2000) but sorted polygons are otherwise only weakly developed. Among the better formed are debris islands $30-40 \mathrm{~cm}$ high on ice-cored moraines at $210 \mathrm{~m}$ altitude on the western side of Round Hill. They have elevated cores $40-70 \mathrm{~cm}$ in diameter that consist of sand and fine gravel with larger clasts to $<6 \mathrm{~cm}$. Their coarse borders are $40-50 \mathrm{~cm}$ wide comprising clasts typically of $<20 \mathrm{~cm}$ (maximum $-70 \mathrm{~cm}$ diameter), smaller clasts tending to stand on edge (pl. 4).

Sorted polygons formed on older till that lacks an ice core are more rudimentary. Along the northern coastal fringe examples occur on low angled $\left(<7^{\circ}\right)$ east-facing slopes atop Round Hill, where slightly convex cores $30-40 \mathrm{~cm}$ wide comprise primarily sand and small pebbles of $<0.5$ $\mathrm{cm}$, flatter clasts being essentially flat-lying. Coarse borders are typically $15-30 \mathrm{~cm}$ wide, formed from clasts generally $<10 \mathrm{~cm}$ (maximum $-30 \mathrm{~cm}$ ) with most clasts too spherical to discern any tendency to be standing on edge. Incipient stone stripes on the cores of the polygons parallel both wind direction and slope angle. Other incipient polygons occur on till above the coastal cliffs just to the north and at $152 \mathrm{~m}$ altitude above the vegetated moraines southeast of Compton Lagoon. On the southern side of Heard Island, a few very rudimentary polygons occur on a $<5^{\circ}$ slope at 


\section{Site 1 Freshly-deposited clasts}
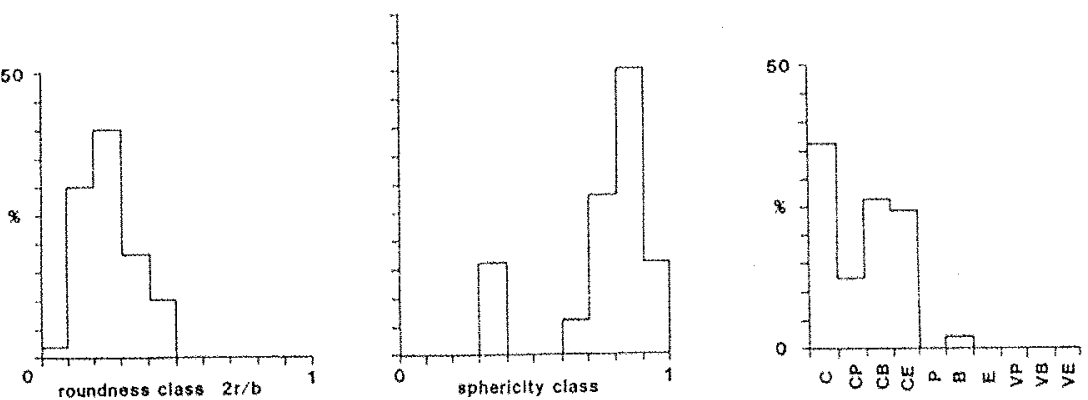

Site 2 Surface clasts
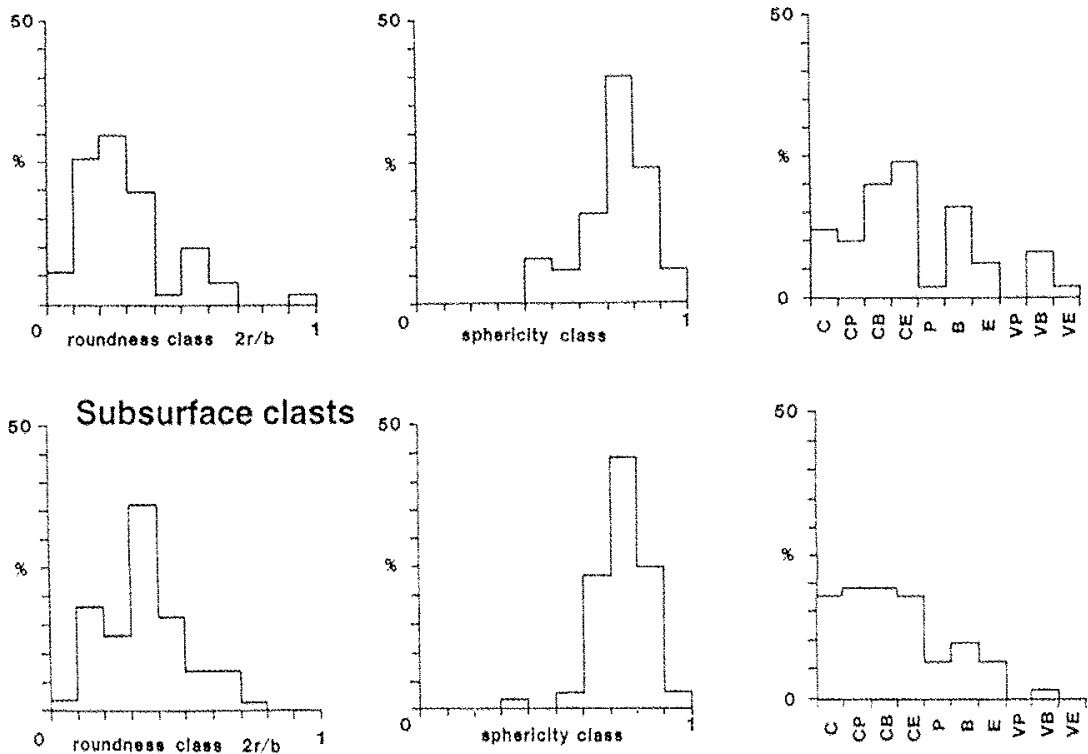

FIG, 2 - Frequency distribution for roundness, spbericity and form of recently-deposited till clasts from site 1 (A) and comparison with older tills at site $2(B=$ substerface, $C=$ surface); and site $3(D=$ subsurface, $E=$ surface). Form classes: $C=$ compact; $P=$ platy; $B=$ bladed $E=$ elongated; $V=$ very.
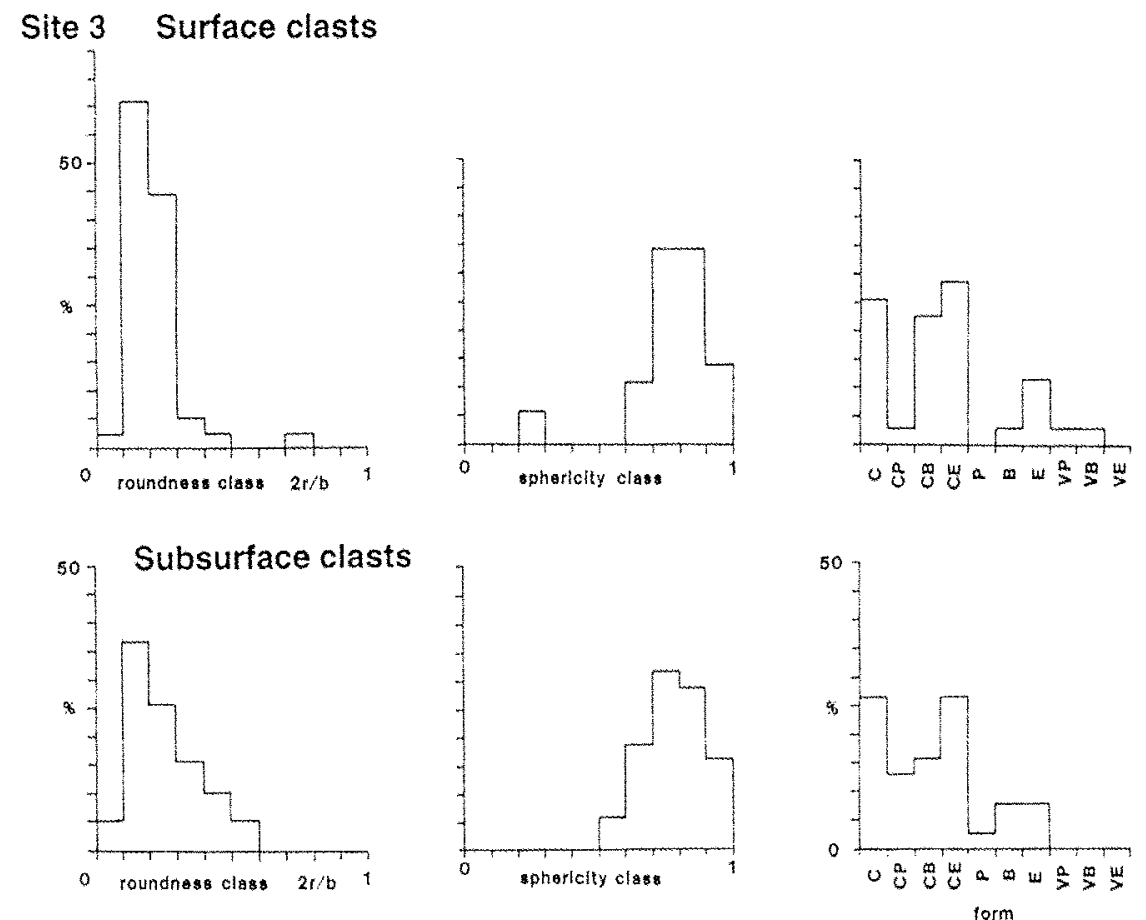



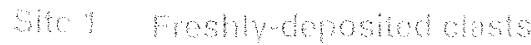

Whe काman cinsts

Gubutmochets

sie sumedoste

FIG. 2 - Frequency distribution for roundness, sphericity and form of recently-deposited till clasts from site $I(A)$ and comparison with older tills at site 2 ( $B=$ subsurface, $C=$ surface $)$; and site $3(D=$ subsurface, $E=$ surface). Form classes: $C=$ compact; $P=$ platy $B=$ bladed $E=$ elongated; $V=$ very. 


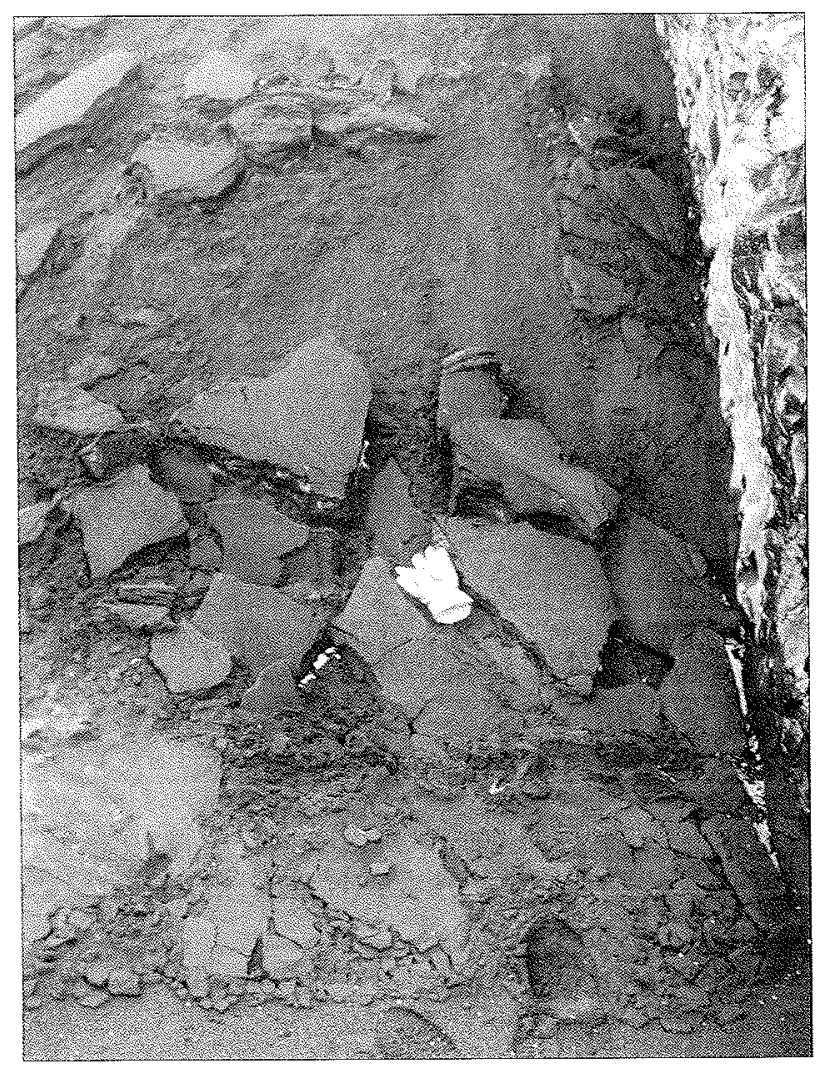

PLATE 3

Small-scale slope instability triggered by superficial thawing of frozen aeolian sediments below Mt Drygalski, involving glissade of ice-cemented slabs $-10 \mathrm{~cm}$ thick and $30-40 \mathrm{~cm}$ wide.

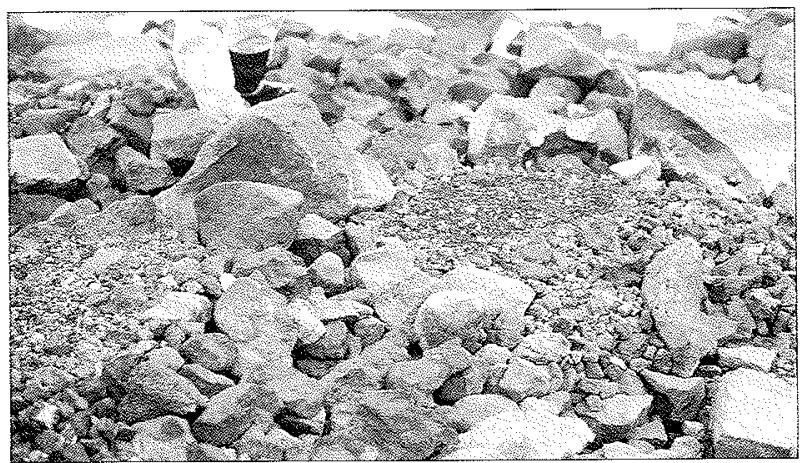

PLATE 4

Debris islands formed on ice-cored moraines at $210 \mathrm{~m}$ on the western side of Round Hill.

$-260 \mathrm{~m}$ altitude on South Plateau. Cores are $100-150 \mathrm{~cm}$ wide, comprising fine gravels (largest clasts $<8 \mathrm{~cm}$ ). Coarse borders, sometimes marked by a subtle hollow, are 30-50 $\mathrm{cm}$ wide and comprise clasts generally $<15 \mathrm{~cm}$ diameter (maximum $-30 \mathrm{~cm}$ ).

Rudimentary sorted stone stripes on South Plateau are formed from sediments of similar calibre to the polygons but they occur on slightly steeper slopes. Better-developed stripes occur on north-facing $22^{\circ}$ slopes of Round Hill ( $380 \mathrm{~m}$ altitude) where coarse borders $-10 \mathrm{~cm}$ wide formed from clasts of generally $<2 \mathrm{~cm}$ (maximum $-10 \mathrm{~cm}$ ) separate irregular sandy stripes $-60 \mathrm{~cm}$ wide that have occasional small pebbles on their surface (pl. 5). Sorted stripes have also been recorded from scoria and ash/sand slopes at the northern base of Mt Dixon (Bergstrom \& Selkirk 2000).

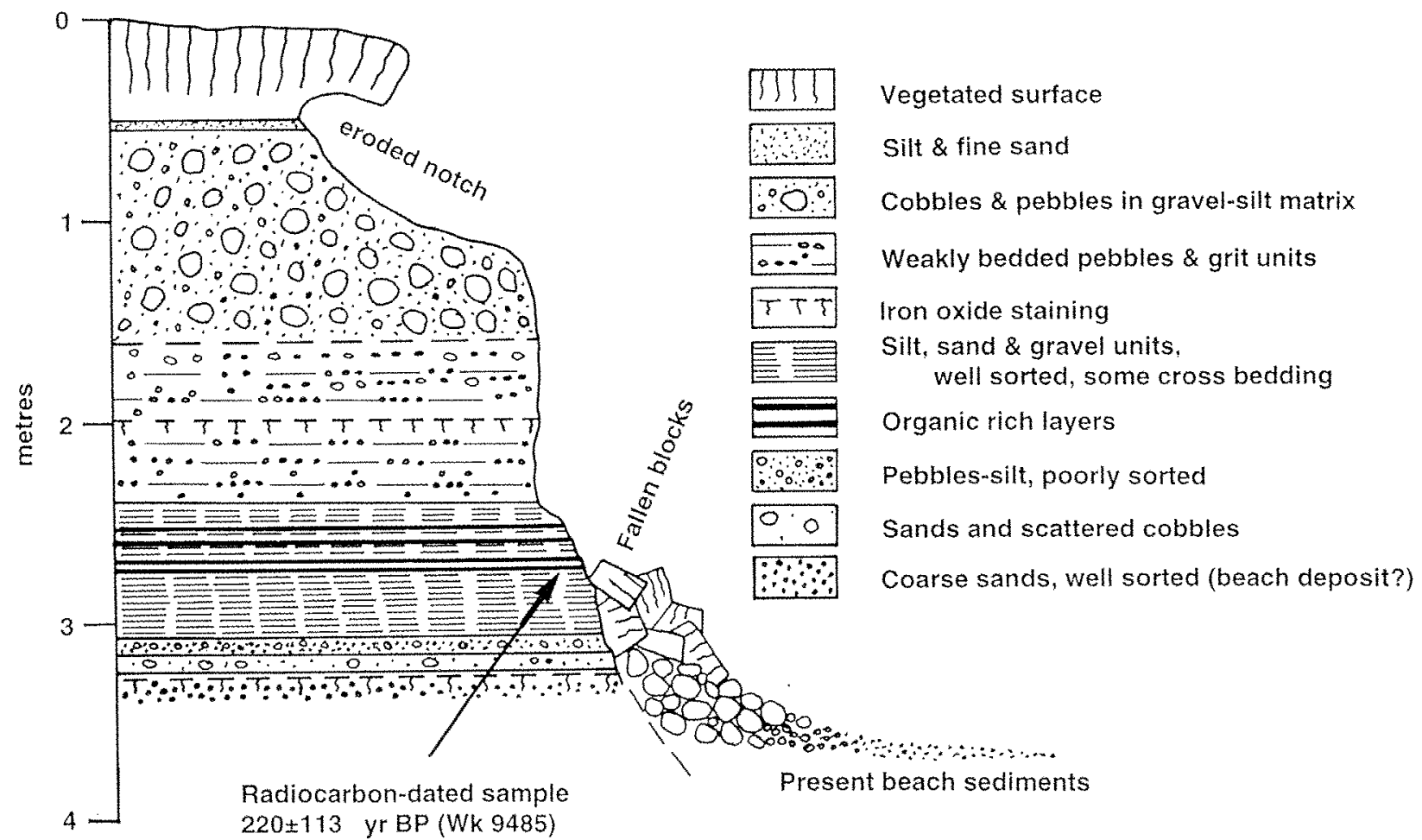

FIG. 3 - Stratigraphy of glaciofluvial sediments on the foreshore at Long Beach, external to the outermost western moraine of the Deacock Glacier. 


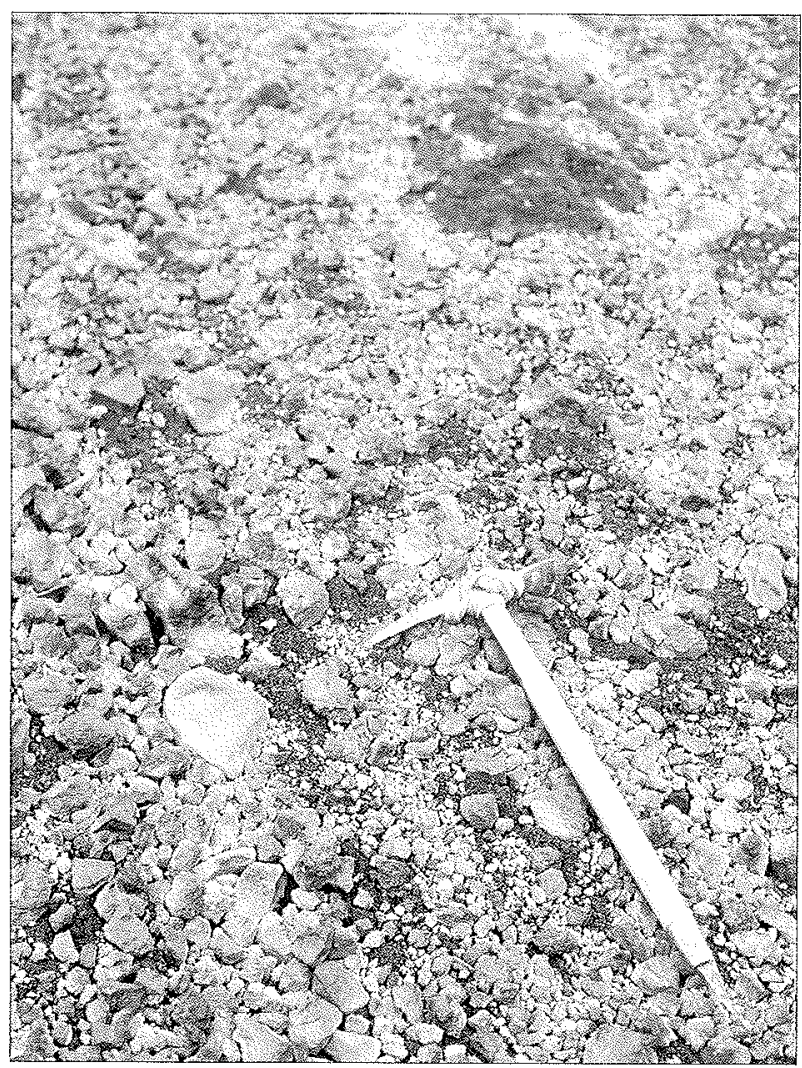

PLATE 5

Rudimentary sorted stripes on Round Hill.

Weakly-developed unvegetated stone-banked terraces occur on west-facing moraine slopes near the summit of Round Hill (pl. 6). One sequence of 16 terraces comprised treads $\leq 1.5 \mathrm{~m}$ wide extending up to $3-4 \mathrm{~m}$ along the hillside and sloping at $-7-15^{\circ}$, separated by risers $40-50 \mathrm{~cm}$ high sloping at $-25-45^{\circ}$. Tread sediment had a calibre of $<2 \mathrm{~cm}$ with clasts of generally no more than $6 \mathrm{~cm}$ (maximum 40 $\mathrm{cm}$ ) diameter forming the risers. Similar terraces occur on the northeastern and southeastern summit slopes of Round Hill. Slightly better-developed examples occur east-southeast of the summit. The best developed flight occurs over an altitudinal range of $-20 \mathrm{~m}$ on a south-facing slope. The dominance of terraces over lobate forms suggests that frost creep rather than gelifluction is the most active process (French 2007).

Vegetation-banked terraces are more common (pl. 7). On slopes $<10^{\circ}$ on $\mathrm{Mt}$ Andree, where vegetation cover may locally exceed $50 \%$, their treads are generally $<100-150 \mathrm{~cm}$ wide (slope $<5^{\circ}$ ) and the risers $20-30 \mathrm{~cm}$ high (slope $2-30^{\circ}$ ). On slopes of $-10^{\circ}-15^{\circ}$, where vegetation is largely confined to risers, well-formed Azorella-banked terraces with treads formed mostly of clasts $<3 \mathrm{~cm}$ (maximum generally $<8 \mathrm{~cm}$ ) extend around the contour. On steeper slopes $\left(15-20^{\circ}\right)$ terraces are narrower and oriented aslant the slope, and small fluvial channels extending downslope between terraces are common. Terrace alignment here is broadly parallel to dominant wind direction. Small notches at the back of some treads are consistent with localised aeolian and/ or Aluvial erosion focused at the foot of the Azorella riser. The shallow depth of these notches, disturbance of treads by pipkrake and alignment of terraces parallel to current wind direction all suggest that these terraces are active, their distribution and character influenced by slope materials and

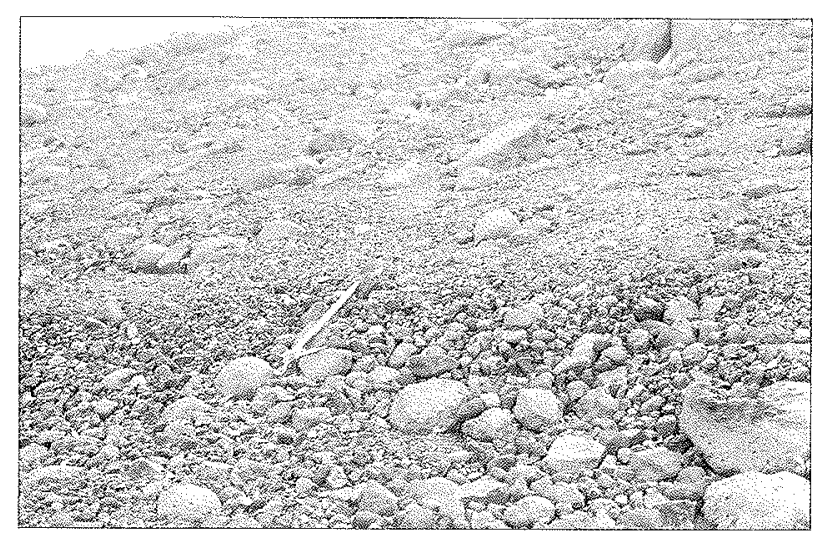

PLATE 6

Small stone-banked terraces on west-facing till slopes near the summit of Round Hill.

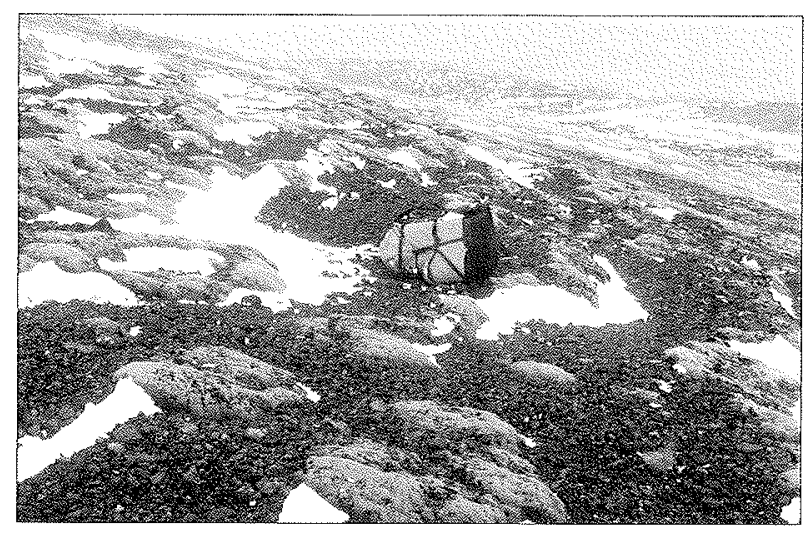

PLATE 7

Vegetation-banked terraces on Mt Andree.

angle, substrate stability, moisture availability, wind and vegetation cover. Only isolated islands of vegetation occur on very steep slopes at $\mathrm{Mt}$ Andree.

Small pits, generally $<40 \mathrm{~cm}$ long, $30 \mathrm{~cm}$ wide and $10-15$ $\mathrm{cm}$ deep (maximum $-120 \mathrm{~cm}$ long and $-20 \mathrm{~cm}$ wide), were encountered on the broad plain below $20 \mathrm{~m}$ altitude between Mt Andree and Mt Drygalski in late October 2000 , formed in sandy aeolian sediments with a thin lag of grit and fine gravel. Lag blown into pits is the likely origin of small pods of gravel in these sediments. Many pits were elongate parallel to aeolian ripples in the sediment. While they occur in an area utilised by burrowing birds, excavation revealed no evidence of burrows extending from their margins, hence they do not appear to have resulted from collapse of burrows. They are instead interpreted as having resulted either from melting of small segregated ice bodies that form seasonally or of snow that accumulated with aeolian sediment (pl. 8).

\section{Cryoturbation phenomena}

Some exposed ground surfaces are armoured by clasts up to cobble size and occasionally boulders. The most likely causes of armouring in a periglacial environment are either upfreezing of clasts or deflation. Upfreezing may occur either by a clast being gripped by the descending freezing plane then being pulled upwards during overall lifting, or because its thermal conductivity favours ice formation beneath it, pushing it upwards (French 2007). Migration of thawed finer material into the resulting void precludes its reoccupation by the 


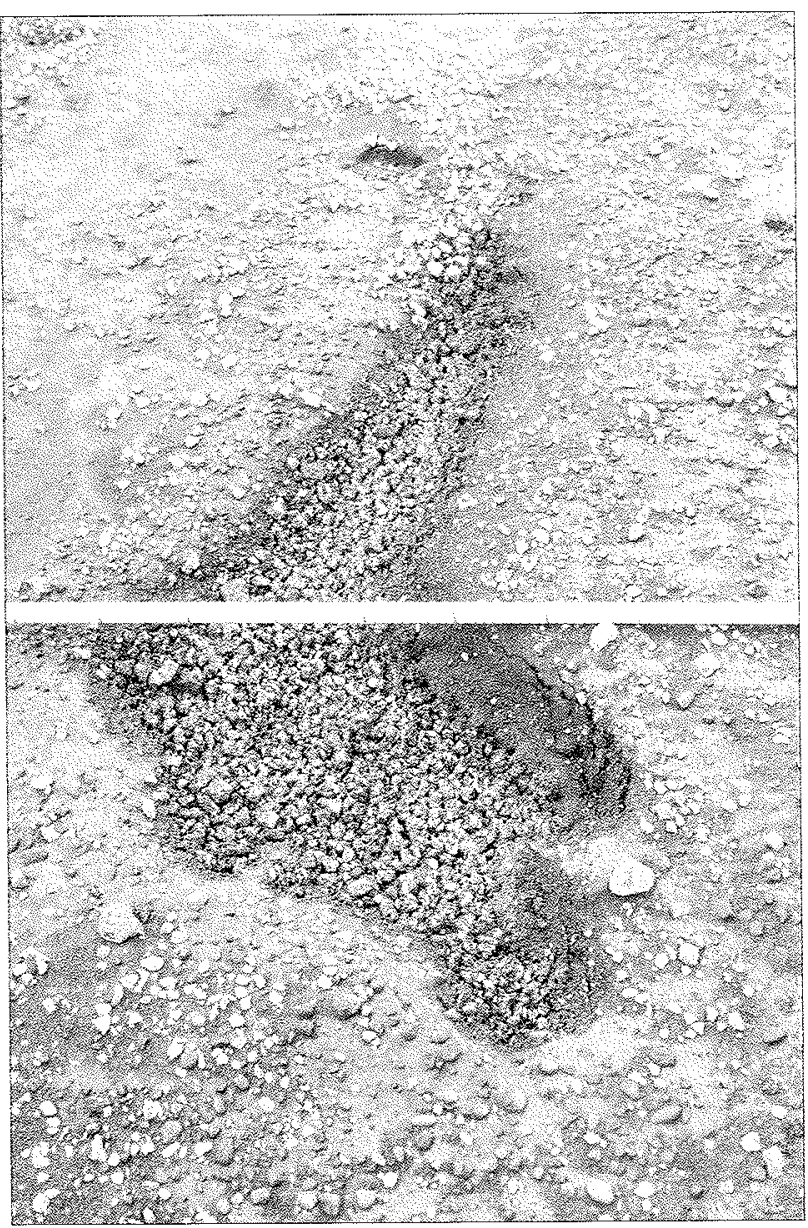

PLATE 8

Melt-pit formed in superficial aeolian sediments east of $M t$ Andree (width is $40 \mathrm{~cm}$ where crossed by staff).

raised clast after thawing. None of our excavated pits revealed thicker silt accumulations beneath clasts; instead, silt caps occurred on clasts at six sites and coatings around clasts in eight cases, but neither caps nor coatings in three other cases. Similarly, exploratory excavation to $-30 \mathrm{~cm}$ depth beneath a veneer of clasts generally $<8 \mathrm{~cm}$ size (maximum $-15 \mathrm{~cm}$ ) at the summit of Round Hill revealed only gritty sand with no accumulation of fine material beneath individual clasts. Hence, the stone veneers are interpreted as primarily lag following deflation.

There is locally abundant evidence of more superficial clast movement by frost action, notably rotation caused by frost pull on the upper edge of surface clasts as the freezing plane descends. Split surface cobbles with the fragments standing on their edge are common between Mt Drygalski and Laurens Peninsula and clasts standing on their edges were encountered in slope deposits at Round Hill and $\mathrm{Mt}$ Andree (b-axis inclination $25-40^{\circ}$ ) and at some excavated pit sites. One typical example below Mt Drygalski comprised a rounded cobble $-8 \mathrm{~cm}$ long split longitudinally, the fracture plane and b-axis standing vertical and the two halves separated by a gap of $-5 \mathrm{~cm}$ filled by aeolian sediment (pl. 9). This result is interpreted as the combined effects of physical weathering, fragment separation by frost action and sediment infill, and fragment rotation or support by frost push or pull. Frost heaving of bare moraine surfaces between cushions of Azorella selago has previously been

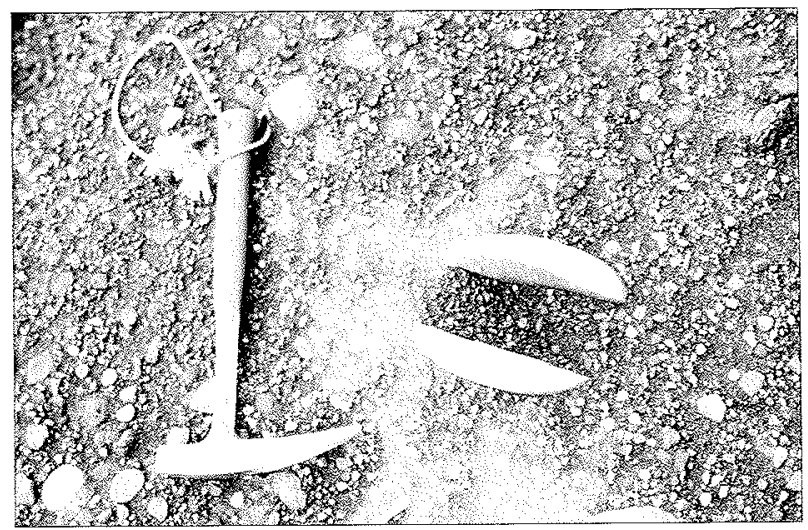

PLATE 9

Split surface clast below Mt Drygalski.

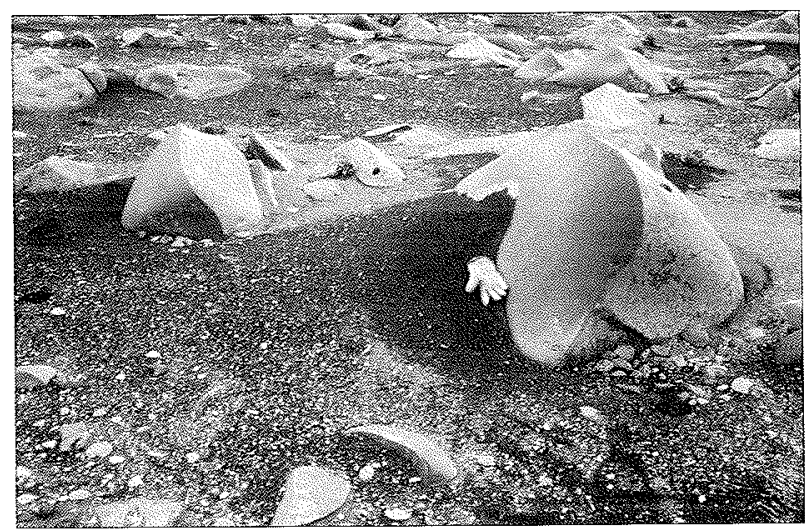

PLATE 10

Ventifacted basalt boulders, southwestern corner of Atlas Cove.

noted by Bergstrom \& Selkirk (2000) and was observed by us in several areas.

Minor involutions were observed on flat, saturated and unvegetated sandur inland of South West Bay. They were $10-20 \mathrm{~cm}$ high and generally less than $100 \mathrm{~cm}$ wide, comprising eruptions of subsurface fine sand and silt onto a surface of sand and fine gravels. More complex forms exhibited a central "crater" with a vertical sediment column forming a core. The regularity and simple form of most involutions, and their environmental setting, suggest that the implied plastic deformation of unfrozen sediment could be caused by cryostatic pressures. However, the presence of permafrost has not been confirmed, hence, pressure between seasonal downward freezing and deeper permafrost cannot be assumed. The formation of periglacial involutions may require more severe depression of ground temperatures than may occur on Heard Island. An alternative explanation for the Heard Island features is that they are the product of density differences, related to generation of high pore water pressures as ice melts. Hence, they may be normal load cast structures, formed due to a reduction in inter-particle friction in finer subsurface sediments beneath heavier gravels that exert downward pressure (French 2007). 


\section{Ground ice conditions}

Segregated ground ice observed in excavated pits comprised pore ice and rare lenses a few tens of centimetres long and up to $1-2 \mathrm{~cm}$ thick. Under the descriptive system of Pihlainen $\&$ Johnston (1963) ice types encountered were predominantly non-visible ice $(\mathrm{N})$ in well-bonded sediments $(\mathrm{Nb})$ with generally limited excess ice (Nbe). Visible ice (V) in some excavations generally comprised individual ice crystals or minor inclusions $(\mathrm{Vx})$ and ice coatings on particles $\left(\mathrm{Vc}_{\mathrm{c}}\right)$. Excess ice content proved greatest in lee-slope cones of aeolian sand at the foot of Mt Drygalski. It was not measured accurately but was estimated at $>50 \%$ from supernatant water in thawed sample bags.

Ice was encountered in only six inspection pits, primarily as lenses in units with slightly higher than normal silt or clay contents. On the northern side of the island ice cementation was encountered below $40 \mathrm{~cm}$ depth in a moraine at $64 \mathrm{~m}$ altitude east of Compton Lagoon and at $4 \mathrm{~cm}$ depth atop Round Hill ( $404 \mathrm{~m}$ altitude) in November 2000. On the southern side of the island very densely ice-cemented till was encountered immediately below the surface in a moraine at $132 \mathrm{~m}$ altitude adjacent to the Gotley Glacier, and clay/ silt-rich till at $160 \mathrm{~m}$ altitude on nearby Lavett Bluff was also densely ice-cemented from the surface. In contrast, no ice core was encountered in $0.5 \mathrm{~m}$ deep excavations in less clay-rich supraglacial moraines at $193 \mathrm{~m}$. These observations are consistent with colder conditions on the southern side of Big Ben and the presence of ice at variable depth according to sediment texture and altitude.

Whether such occurrences represent permafrost or seasonal ice is unresolved. Aeolian sand accumulations northwest of Mr Drygalski remained densely ice-cemented below $20 \mathrm{~cm}$ depth in November 2000, but the extent to which this ice persists through summer is not known. Ice-cemented aeolian sands were encountered in the entrance to lava tube caves at <100 $\mathrm{m}$ altitude on Azorella Peninsula in March 1997. A permafrosted condition is suggested by the persistence of this ice at the end of the melt season.

Landforms indicative of permafrost, such as ice-wedge polygons, ice-cored mounds and pingos, and palsas or peat plateaus, were not recognised. No thermokarstic landforms indicative of permafrost degradation, such as ground-ice slumps, depressions, thaw lakes and beaded drainage systems, were recorded. Collapse pits in the Dovers Moraine complex are not of periglacial origin but have formed in response to melting of buried glacier ice.

\section{Periglacial aeolian landforms}

Spectacularly developed ventifacts occur at the western end of Atlas Cove where basalt boulders are subject to abrasion by windblown sediments derived from glaciofluvial and raised coastal deposits between Big Ben and Laurens Peninsula, and by windblown ice crystals. Boulders up to $1.5 \mathrm{~m}$ wide occupy $-30 \%$ of the ground surface, standing $40-60 \mathrm{~cm}$ above it, with freshly eroded basalt on their windward face and $60-80 \%$ lichen-cover on their leeward side (pl. 10). Small ventifacted clasts from Drygalski Formation sediments collected by P. J. Stephenson, are described by Sugden (1968). Some beach cobbles above the present limit of wave action on Elephant Spit are also ventifacted (fig. 4), as are a few glacial clasts on the Winston Lagoon barrier.

Wind-eroded swales flanked by retreating scarps up to

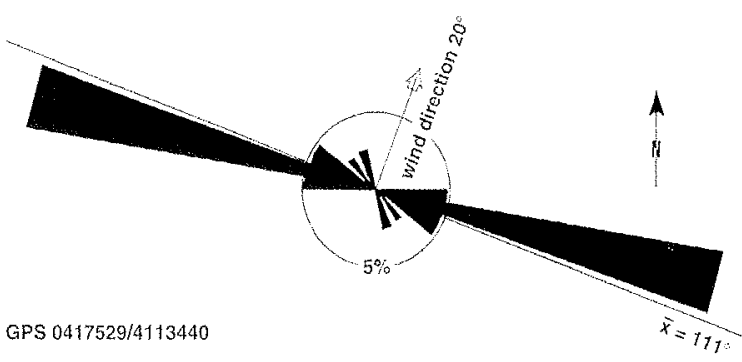

FIG. 4 - Orientation of crests on ventifacted beach cobbles midway across the apex of Elephant Spit (distance from HWM $130 \mathrm{~m}$, altitude $2.2 \mathrm{~m}$ ), indicating predominance of SSW winds $(n=25)$.

$2 \mathrm{~m}$ high, in which numerous plant roots are exposed, occur amid vegetated ash and scoria at Saddle Point, on the northwestern extremity of Laurens Peninsula, and elsewhere. Behind the southern beach just east of Dovers Moraine is a 50 -m-wide zone of exposed plant roots where vegetation and soil have been stripped by the wind, probably assisted by seals and penguins. This general area is a major source of sandstorms that sweep across the apex of Elephant Spit. Elephant seal harems along the northern side of this spit sometimes form a local "snow fence" that results in localised sand deposition, resulting in temporary islands of sand rising $1 \mathrm{~m}$ or more above the beach cobbles (Green 2000). Similar but smaller accumulations occur on the Winston Lagoon bar.

\section{INTERPRETATION OF THE PERIGLACIAL ENVIRONMENT}

Only limited development of periglacial landforms has occurred on Heard Island. Classical indicators of permafrost, such as ice wedges, form in colder environments when exposed ground is cooled sufficiently to cause shrinkage of ice in the soil and cracking of the frozen ground. Subsequent freezing of meltwater in the voids perpetuates the cracks. If soil is sufficiently ice-rich, cracking can occur with a temperature drop of as little as $4^{\circ} \mathrm{C}$ in the below-zero range (French 2007). However, the coldest temperature recorded from glacier-free areas of Heard Island between 1997 and 2000 was only $-8.4^{\circ} \mathrm{C}$, much warmer than the temperatures of $-15^{\circ} \mathrm{C}$ to $-20^{\circ} \mathrm{C}$ generally considered necessary for ice wedge formation (French 2007).

The maritime environment of Heard Island is one factor that inhibits some forms of periglacial activity. Freeze-thaw action is inhibited by release of latent heat by summer melting of ground ice and rapid warming of the ground by snowmelt infiltration (French 2007). Winter snow cover combined with meltwater and liquid precipitation during summer moderates temperature fluctuations at the ground surface. Consistently cloudy conditions inhibit escape of long-wave radiation and also solar heating that might otherwise elevate ground temperature above atmospheric temperature. Latent heat is released as abundant liquid water freezes during autumn, again stabilising regolith temperatures.

There are broad similarities in the types of periglacial features present on Heard, Marion, Crozet and Kerguelen islands. For example, sorted nets are present on all four islands. However, they are markedly less common on Heard 
Island. With the exception only of the polygons described from the southern base of Anzac Peak by Bergstrom \& Selkirk (2000), the polygons on Heard Island are generally smaller than those described from Îles Kerguelen or Marion Island (Hall 1983b). A relative paucity of stone-banked and vegetation-banked terraces is not unique to Heard Island, for they are also rare on Illes Kerguelen compared to Marion Island. But overall, and notwithstanding its location south of the Antarctic Convergence, the range and development of periglacial landforms on Heard Island is much more limited than on the other islands.

Jacka \& Ruddell (1998) concluded from model studies that the temperature record from Îles Kerguelen provided the best available proxy for Heard Island. Nevertheless, the number of atmospheric freeze-thaw cycles on Heard Island from 1998-2000 (60-80) was significantly less than recorded from T̂les Kerguelen (120) by Aubert de la Rue (1959). Even allowing for the suggestion that ground frosts may be twice as numerous as air frosts, the number of ground frosts on Heard Island is likely to be less than the 200-236 recorded from Îles Kerguelen where maximum ground penetration of freeze-thaw cycles was still only $0.05 \mathrm{~m}$ (Aubert de la Rue 1959, Troll 1960, Hall 1983b). On Marion Island, air temperatures of $-2^{\circ} \mathrm{C}$ or lower occur at sea level on 48 days $/$ year (freeze amplitude $3.4^{\circ} \mathrm{C}$ ) and on 111 days/year at 500 m altitude (mean freeze amplitude $-4.1^{\circ} \mathrm{C}$ ) (Hall 1979b). The number of precipitation days per year on Heard Island (300) is comparable to the number on Îles Kerguelen (334) and Marion Island (300).

Lesser development of periglacial landforms on Heard Island relative to other islands in the southern Indian Ocean cannot be attributed solely to climatic differences. Greater physical weathering of longer-exposed rock outcrops and more pronounced terrace development on Mt Andree than within any area deglaciated within the past two centuries indicates duration of exposure is a significant determinant of periglacial landform development on Heard Island. That the most pronounced sorted polygons occur on relatively recent moraines is probably due to the presence of unmelted ice cores that inhibit infiltration, and thereby facilitate generation of high cryostatic pressures in the till during seasonal freezing from the surface. The absence of such well-developed polygons from older moraines probably reflects ice core melting and reworking.

The periglacial landforms recorded from Heard Island are much less well-developed than those known from Australia's other major sub-Antarctic terrain, Macquarie Island $\left(54^{\circ} 37^{\prime} \mathrm{S}, 158^{\circ} 54^{\prime} \mathrm{E}\right)$, where sorted stone circles up to $100 \mathrm{~m}$ in diameter and very well-developed terraces are present. This difference is despite Macquarie Island's broadly similar latitude to Heard Island and position north of the Antarctic Convergence. Whereas most of Heard Island has previously been glacier-covered, there is no evidence to suggest past glaciation of Macquarie Island, hence periglacial landforms have had much longer to develop on Macquarie Island, which has remained exposed through several Glacial Climatic Stages. However, the very well-developed terraces on Macquarie Island do not appear to be relict, Selkirk (1998) having recorded surface gravel movement of $38-148 \mathrm{~mm} /$ year on vegetation-banked terraces, facilitated by the presence of liquid water, frequently groundwater seepage.

The low altitude of most ice-free terrain on Heard Island (generally $<250 \mathrm{~m}$ ) is another limiting factor on the extent of its periglacial landforms. There is considerable ice-free terrain to over $800 \mathrm{~m}$ on Îles Kerguelen, while Îsles Crozet is glacier-free to its $1090 \mathrm{~m}$ summit and on Marion Island exposed ground occurs to $-1200 \mathrm{~m}$. Similarly, Macquarie Island rises to $433 \mathrm{~m}$. Development of periglacial landforms also appears to be partly a logical consequence of the relative extent of exposed ground. Only $-110 \mathrm{~km}^{2}$ of Heard Island is glacier-free, compared to $287 \mathrm{~km}^{2}$ on Marion Island, 325 $\mathrm{km}^{2}$ in Îsles Crozet and $7215 \mathrm{~km}^{2}$ in Îles Kerguelen.

Sketches by sealers indicate that the ice cover on Heard Island in the 1850 s to 1870 s was more extensive than at any time since. The radiocarbon date of $220 \pm 113^{14} \mathrm{C}$ yrs BP (Wk 9485) obtained from plant material beneath gravels at Long Beach indicates that some presently stable surfaces that were not glacier-covered in historical time are nevertheless young. Historical and photographic records suggest there was no significant change in glacier extent before 1929. In 1947 glaciers still covered $79 \%$ of Heard Island, but by the end of the 1980 s only $70 \%$ of the island remained glacier-covered (Allison \& Keage 1986, Ruddell 2001). There has been continuing subsequent recession (Ruddell 2006, Kiernan \& McConnell 1999, 2002, Budd 2000). Hence, only a relatively small proportion of Heard Island has been exposed to periglacial processes prior to the past two centuries, with the well-formed vegetation-banked terraces on Mt Andree occurring in one of the longest-exposed areas. In contrast, extensive areas of Kerguelen have been deglaciated at least throughout the Holocene. The largest sorted stripes on Îles Kerguelen and rubble-covered stonebanked terraces on Marion Island are both regarded by Hall $(1983 a, b)$ as fossil and indicative of greater depth of sorting earlier in the Holocene than is occurring at present. Given unresolved questions regarding the prior extent of glaciers on Îles Kerguelen (Bellair 1965, 1969 a,b, Nougier 1966, 1970, 1972, Hall 1984), it remains possible that significant parts of it remained exposed even during the Last Glacial Maximum.

Periglacial landform development on Heard Island is likely to have been further inhibited by the climatic warming that has driven land surface exposure by glacier retreat. AWS data indicate temperatures over the 1997-2000 period were $-0.6^{\circ} \mathrm{C}$ cooler than for $1981-82$ but $-0.9^{\circ} \mathrm{C}$ warmer than 1948-54. From 1948-54 mean daily temperatures generally remained below $0^{\circ} \mathrm{C}$ from mid-June until mid-October. However, mean temperatures below $0^{\circ} \mathrm{C}$ now occur only between mid-July and late September, and temperatures above $0^{\circ} \mathrm{C}$ generally occur even on winter days. Sea surface temperatures (SST) measured at Spit Bay in winter 1992 were $-0.5-2.0^{\circ} \mathrm{C}$ warmer than figures recorded for the same months at Atlas Cove in 1950, although the two sampling sites were not entirely comparable (Green 2000). Mean annual SST at $52.5^{\circ} \mathrm{S}$ was $0.3^{\circ} \mathrm{C}$ cooler in $1947-54$ than in 1997-2000.

Notwithstanding their limited impact on the landforms of Heard Island, periglacial processes remain significant for management of this World Heritage Wilderness Reserve. There are important interactions between periglacial processes and botanical colonisation, most conspicuously involving evolution of vegetated terraces. Any accelerated devegetation caused by human impacts would expose additional areas to periglacial erosion and there are also important ecological linkages. Thawing of the plain between Big Ben and Laurens Peninsula and the arrival of the birds that excavate breeding burrows in these sediments appeared exquisitely synchronised in November 2000 , the area being re-occupied by thousands of birds within a few hours of the first summer rains and accelerated thawing. It is conceivable 
that burrowing birds might exploit natural weaknesses along meltout voids. Not only can trampling collapse bird burrows, but these surfaces were sensitive to pedestrian disturbance at the onset of the melt season in late October 2000 when footprints $1 \mathrm{~cm}$ deep made in the morning had deepened to $4-6 \mathrm{~cm}$ by mid-afternoon. The fact that involutions seemed most pronounced along a route traversed daily by small parties travelling on foot suggests that the densitycontrolled equilibrium within some saturated sediments can be very delicate (French 2007).

Heard Island is an important location for further research into the varying periglacial environments that occur around the globe, given its position in the southern Indian Ocean south of the Antarctic Convergence. Hence, further documentation of its periglacial phenomena is warranted. Unfortunately, logistical difficulties make the detailed process studies that are the most critical requirement very difficult to achieve. However, a focus on sedimentological structures, sorting and fabrics of periglacial phenomena would allow inferences on processes to be refined (Hall 2002, Boelhouwers et al. 2003). Investigation of the significance of chemical weathering on Heard Island would also be very worthwhile.

\section{CONCLUSIONS}

Periglacial landforms are developed to only a limited extent on Heard Island. No evidence of thermal contraction cracking of the ground was detected. Superficial patterned ground is interpreted as having been formed by freeze-thaw cycles, but sorted polygons, terraces and stripes are only weakly developed. The absence of deep cryoturbation is attributable to the maritime climate and relatively recent exposure of most ground surfaces, in response to climatic warming that is simultaneously reducing the severity of the periglacial climate.

\section{ACKNOWLEDGEMENTS}

We are grateful to Will Powell and Paul Scott for company and assistance in the field, to Doug Thost for assistance in obtaining climate data, and to Ellen Kiernan for assistance with the morphometric analyses. Peter McIntosh, Damian Gore, Jon Stephenson and Pat Quilty provided helpful comments on a draft manuscript. The research was made possible by an Australian Antarctic Science Grant.

\section{REFERENCES}

Allison, I. \& Keage, P. 1986: Recent changes in the glaciers of Heard Island. Polar Record 23: 255-271.

Aubert de la Rue, E. 1959: Phenomenes periglaciales et actions coliennes aux Îles Kerguelen. Memoir Institute Scientifrque de Madagascar E: 1-21.

Bellair, P. 1965: Un example de glaciation aberrante, les Îles Kerguelen. Committee Nationale Francais Recherches Antarctiques 11: 1-27.

Bellair, P. 1969a: Donnes actuelles sur les Archipels des Crozet et des Kerguelen. In Van Zinderen Bakker, E.M. (ed.): Palaeoecology of Africa and of the Surrounding Islands and Antarctic. Balkema, Cape Town: 165-174.

Bellair, P. 1969b: Soil stripes and polygonal ground in the sub-
Antarctic islands of Crozet and Kerguelen. In Pewe, T.L. (ed.): The Periglacial Environment, Past and Present. McGill-Queen's University Press, Montreal: 217-222.

Bergstrom, D. \& Selkirk, P.M. 2000: Terrestrial vegetation and environments on Heard Island. In Banks, M.R. \& Brown, M.J. (eds): Heard Island Papers. Papers and Proceedings of the Royal Society of Tasmanict 133(2): 33-46.

Boelhouwers, J., Holness, S. \& Sumner, P. 2003: The maritime Subantarctic: a distinct periglacial environment. Geomorphology 52: 39-55.

Budd, G.M. 2000: Changes in Heard Island glaciers, king penguins and fur seals since 1947. In Banks, M.R. \& Brown, M.J. (eds): Heard Island Papers. Papers and Proceedings of the Royal Society of Tasmania 133(2) 47-60.

Colhoun, E.A. \& Peterson, J.A. 1986: Quaternary landscape evolution and the cryosphere: research progress from Sahul to Australian Antarctica. Australian Geographical Studies 24: 145-167.

Corty, M.A., Goldberg, P. \& Macphail, R. 1989: Soils and Micromorphology in Archaeology. Cambridge University Press, Cambridge: 206 pp.

French, H.M. 2007: The Periglacial Environment. 3rd ed. Wiley, Chichester: $458 \mathrm{pp}$.

Green, K. 2000: Coastal studies at Heard Island 1992/93: Changes in sea surface temperature and coastal landforms. In Banks, M.R. \& Brown, M.J. (eds): Heard Island Papers. Papers and Proceedings of the Royal Society of Tasmania. 133(2): $27-32$.

Hall, K. 1979a: Sorted stripes orientated by wind action: some observations from sub-Antarctic Marion Island. Earth Surface Processes 4: 281-289.

Hall, K. 1979b: Late glacial ice cover and palacotemperatures on sub-Antarctic Marion Island. Palaeogeography, Palaeodimatology, Palaeoecology 29: 243-259.

Hall, K. 1981: Observations on the stone-banked lobes of Marion Island. South African Journal of Science 77: 129-131.

Hall, K. 1983a: Sorted stripes on sub-Antarctic Kerguelen Island. Earth Surface Processes and Landforms 7: 45-51.

Hall, K. 1983b: Observations of some periglacial features and their palaeoenvironmental implications on sub-Antarctic islands Marion and Kerguelen. South African Journal of Antarctic Research 13: 35-40.

Hall, K. 1984: Evidence in favour of an extensive ice cover on sub-Antarctic Kerguelen Island during the last glacial. Palaeogeography, Palaeoclimatology, Palaeoecology 47 : 225-232.

Hall, K. 2002: Review of present and Quaternary periglacial processes and landforms of the maritime and sub-Antarctic region. South African Journal of Science 98: 71-81

Harland, W.B. 1957: Exfoliation joints and ice action. Joumal of Glaciology 3: 21, 8-10.

Jacka, T.H. \& Ruddell, A. 1998: Construction of a temperature record for Heard Island, and comparison with glacier Auctuations. American Geophysical Union Fall Meeting, San Francisco, California, USA, supplement to EOS, Transactions: F55 (Abstracts U31E-04): 32 .

Kiernan, K. \& McConnell, A. 1999: Geomorphology of the SubAntarctic Australian Territory of Heard Island-McDonald Island. Australian Geographer 30: 159-195.

Kiernan, K. \& McConnell, A. 2002: Glacier retreat and meltlake expansion at Stephenson Glacier, Heard Island World Heritage Area. Polar Record 38(207): 297-308.

Kuenen, P.H. 1956: Experimental abrasion of pebbles. 2. Rolling by current. Journal of Geology 64: 336-338.

Lambeth, A.J. 1950: Heard Island: geography and glaciology. Royal Society of New South Wales Journal and Proceedings 86: 92-98.

McGreevy, J.P. \& Whalley, W.B. 1982: The geomorphic significance of rock temperature variations in cold environments: a discussion. Arctic and Alpine Research 14: $157-162$. 
Markov, K.K. 1971: Kerguelen Islands. Antarctica Commission Reports 1968: 43-58.

Nougier, J. 1964: Observations periglaciaires dans l'Archipel de Kerguelen, Terres Australes et Antarctiques Francaises. Zeitschrift fur Geomorphologie 8: 143-149.

Nougier, J. 1966: Lacs frontaux des glaciers de P'archipel de Kerguelen. Revue of Geographie Physical and Geology Dynamique 8(2): 161-169.

Nougier, J. 1970: Contribution a l'etude geologigique et geomorphologique de Î̂es Kerguelen, Committee Nationale Francais. Recherches Atarctiques 27(2): 379-381.

Nougier, J. 1972: Aspects de mopho-tectonique glaciaire aux Îles Kerguelen. Revnue of Geographie Physical and Geology Dynamique 14(5): 499-505.

Pendlebury, S.F. \& Barnes-Keoghan, I.P. 2007: Climate and climate change in the sub-Antarctic. In Selkirk, P.M Quilty, P.G. \& Davies, M. (eds): The Sub-Antarctic. Papers and Proceedings of the Royal Society of Tasmania 141(1): $67-82$.

Pihlainen, J.A. \& Johnston, G.H. 1963: Guide to a Field Description of Permafrost. National Research Council of Canada, Associate Committee on Snow \& Soil Mechanics, Technical Memorandum 79 (National Research Council Publication 7576): $262 \mathrm{pp}$

Ruddell, A. 2001: Our subantarctic glaciers: Why are they retreating? Australian Antarctic Magazine 2: 33-34.

Ruddell, A. 2006: An inventory of present glaciers on Heard Island and their historical variation. In Green, K. \& Woehler, E. (eds): Heard Island: Southern Ocean Sentinel. Surrey Beatty \& Sons, Chipping Norton: 28-51.
Selkirk, J. M. 1998: Active vegetation-banked terraces on Macquarie Island. Zeitschrift fur Geomorphologie 42: 483-496.

Sneed, E.D. \& Folk, R.L. 1958: Pebbles in the Colorado River, Texas: A study in particle morphogenesis. Joumal of Geology 66: 114-179.

Stephenson, J., Barling, J., Wheller, G. \& Clarke, I. 2006: The geology and volcanic geomorphology of Heard Island. In Green, K. \& Wochler, E. (eds): Heard Island: Southern Ocean Sentinel. Surrey Beatty \& Sons, Chipping Norton: 10-27.

Sugden, W. 1968: Ventifacts. In Fairbridge, R.W (ed.): The Encyclopedia of Geomorphology. Dowden, Hutchinson \& Ross, Stroudesburg, Pennsvlvania, USA: 1192-1193.

Thost, D. \& Allison, I. 2006: The climate of Heard Island. In Green, K. \& Woehler, E. (eds): Heard Island: Southern Ocean Sentinel. Surrey Beatty \& Sons, Chipping Norton: $52-68$

Troll, C. 1960: The relationship between the climates, ecology and plant geography of the southern cold temperature zone and of the tropical high mountains. Proceedings of the Royal Society of London B 152: 529-532.

Truswell, E.M., Quilty, P.G., McMinn, A., Macphail, M.K. \& Wheller, G. 2005: Late Miocene vegetation and palaeoenvironments of the Drygalski Formation, Heard Island, Indian Ocean: evidence from palynology. Antarctic Science 17: 427-442.

Whalley, W.B., Douglas, D.R. \& McGreevy, J.P. 1982: Crack propogation and associated weathering in igneous rocks. Zeitschrift fur Geomorphologie 26: 33-54.

(accepted 26 February 2008) 